\title{
The Effect of Multisensory Teaching Method on The Students' Reading Achievement
}

\author{
Diani Syahputri \\ Lecturer of Faculty of Teacher Training and Education \\ University of Muhammadiyah Sumatera Utara (UMSU), Indonesia \\ dianisyahputri@gmail.com
}

\begin{abstract}
This study aims to investigate the effect of Multisensory Teaching Method on the Students' Reading Achievement. This research applied experimental research. The population of this research was taken from the Seven grade and the second year students of junior high school in SMP Swasta PGRI 3 Medan at academic 2017/2018. There were 3 classes consisting 113 students. This research was applied cluster random sampling. This research used experimental research design namely One group pre-test and post-test, Therefore, the research took one class as the experimental class. The sample was taken from the students in VII-1 who consisted of 38 students. The researcher were given treatment by Multisensory Teaching Method. The instrument of research is a multiple choice test which consist of 20 items. The data were analyzed by using $t$-test formula. The result of the data showed that $t_{\text {observe }} 13.3>t_{\text {table }} 1.68$ with degree of freedom $(d f)=n-k$. The hypothesis was accepted. It proves that Multisensory Teaching Method significantly effect to the students' reading achievement.
\end{abstract}

Keywords : multisensory teaching method, reading comprehension

\section{Introduction}

There are four language skills in English, they are: listening, speaking, reading and writing. Listening competence is universally 'larger' than speaking competence. It is any wonder, that in recent years the language teaching profession has placed a concerted emphasis on listening comprehension. Speaking and listening skills are closely intertwined. The interaction between these two models of performance is applied especially to conversation, the most popular discourse category in the profession. Reading is also one of the most important skills in learning a language besides listening, speaking and writing. It is certainly not easy to present the English reading to Indonesian students whose language system is different.

Reading in their own language is much easier than that of the language learned because they have mastered the vocabulary and the structure of their own. As reading plays an important role in language learning, it would be better that this teaching is wisely done. To understand a text students must have a good command of the vocabulary of the target language. The reader uses knowledge, skills and strategies to determine what the text meaning is. Haris (2002:22) states that, reading is complex ability. Reading is not the activity at the symbol of written simply. The various capabilities are deployed by a reader, so he will be able to understand the reading material. Reading activities are also an activity that is active speaking receptive.

For students, reading is not only in the subject learned. But reading is also a role in knowing the various kinds of advanced in science and technology continue to grow. Through reading, advancement of science and technology can be known and undrestood before it can be applied. By reading, the students will get much information from the text which they read.

Based on the researcher's observation during as the lecturer's guidance at SMP swasta PGRI 3 Medan of Grade VII-7 on 2017/2018 academic year. The researcher predicted that students in the school still got difficulties in reading and they did not understand what they have read, it turns out after doing research in the school of 113 students who consists of 3 classes just a few students who can reach the value of KKM (Minimum Criteria of Mastery 
Learning). Based on data obtained from the school was still many students who have trouble in reading so many students who can not reach the standard KKM that have been determined by the school, as the value of KKM prescribed school by the value of the 75 . The data can be seen from the number of the students namely 113 people consists of three class and just $36 \%$ are completely KKM and 64\% not complete KKM. (The source of taken from her exam result MID semester students and practice read the lesson, 2017/2018).

From the exiting data researcher found some problem faced by the students in reading. They also found the difficulties in reading especially reading descriptive text. They often failed in reading texts because of lack of vocabularies and technique in reading. The problem also comes from the teacher's technique and method in teaching. During the researcher's observation, the teacher still applied a traditional method, the teachers asked the students to write things in their exercise books freely, read the texts by heart and opened dictionary anytime they stuck on using words that they didn't know. It caused the students bored and did not have a concentration in learning so, they could not gain the purpose of reading.

\section{Review of Literature}

\subsection{Reading}

Reading is one of the most important skills in learning a language besides listening, speaking and writing. The fundamental goal for any reading activity is knowing enough science concepts and knowing the language. To Indonesian students this is a bridge to understand scientific books that they read. As they lack knowledge of English they often encounter difficulties when reading their compulsory books written in that language. Klingner (2007:8) reading comprehension is multicomponent, highly complex process that involves many interaction between readers and what they bring to the text (previous knowledge,strategy use) as well as variabels related to the text itself(interest in text, understanding of text types).

Reading may be defined as the meaningful interpretation of printed and written verbal symbols. For the beginner, reading is concerned mainly with learning to recognize the printed symbols that represent language and to respond intellectually and emotionally when being asked about the content of the text he has read. The reasoning side of reading becomes increasingly important as word recognition is mastered.

As proficiency in reading increases, individuals learn to adapt their reading strategies in accordance with the purpose for reading and the restriction imposed by the material. The nature of reading task, therefore, changes a learner's progress to the more nature levels (Albert J. Harris \& Edward R. Sipay p.13).

The definitions of reading above can be concluded that reading is one of skills in English which is needed in the process to interpretation of graphic symbols and written symbols. We can give respond about the content of reading materials we has read, we are also can get the message from the reading materials.

In addition, reading activity is not focus on reading the written words but should comprehend of the text. There are some definitions of reading which are given by experts. Reading is a fluent process which involved the reader and the reading material and building meaning. It means that the reader should know the information and the ideas of the text to get the meaning and the way readers read the text that have influenced their comprehension.

When we begin to read, we actually have a number of initial decisions to make, and we usually make these decisions very quickly, almost unconsciously in most cases. Most of people read for general comprehension. Here we might read a novel, short story, a newspaper article or a report of some type to understand the information in the text, to be entertained and to use the 
information for a particular purpose. Cadlin and Hall (2002:13) states that there are seven purposes of reading, they are:

1) Reading to search for simple information and reading to skim

Reading to search for simple information is a common reading ability, through some researchers see it as a relatively independent cognitive process. It is use so often in reading tasks that it is probably best seen as a type of reading ability. In reading to search, we typically scan the text for a specific piece or information or a specific word. It involves, in essence, a combination of strategies for guessing where important information might be in the text, and then using basic reading comprehension skills on those segments of the text until a general idea is formed.

2) Reading to learn for texts

Reading to learn typically occurs in academic and professional contexts in which a person needs to learn a considerable amount of information from a text. Reading to learn is usually carried out at a reading rate somewhat slower than general reading comprehension. In addition, make stronger inference demands than general comprehension to connect text information with background knowledge.

3) Reading to integrate information, write and critique texts

Reading to integrate information requires additional decisions about the relative importance of complementary, mutually supporting or conflicting information and the likely restructuring of a theoretical frame to accommodate information from multiple sources. Both reading to write and reading to critique texts may be task variants of reading to integrate information.

4) Reading for general information

The notion of general reading comprehension has been intentionally saved for the last in this discussion for two reasons. First, it is the most basic purpose for reading, underlying and supporting most other purpose for reading. Second, general reading comprehension is actually more complex than commonly assumed. Reading for general comprehension when accomplished by a skilled fluent reader, requires very rapid and automatic processing of words, strong skills in informing a general meaning representation of main ideas, and efficient coordination of many processes under very limited time constraints. The purpose of reading above can be concluded that reading is used to search information, to write and to give any critique about the contents of the text or reading materials.

Reading with comprehension means understanding what has been read. Comprehension involves understanding the vocabulary seeing the relationship among words and concepts, organizing idea, recognizing authors' purpose, making judgment and evaluating. Word important factor in determining the degree of comprehension. According to Heilman $(1981 ; 265)$ reading is a process of making sense of written ideas through meaningful interpretation interaction with language. A good reader is one who understands what he reads, and the faster he able to get meaning from his reading the more efficient he is. The rate of comprehension needs to be adjusted to the purpose of reading skills, and like skill development in any area, reading rate can be improved with training and with practice.

From the statement, it is clearly stated that comprehension or understanding in every reading activity is an important part of skill learning. The student must be able to read a text consisting of many sentences and select the main idea to which all the sentences refer. After the reader is able to comprehend what the most important thought is, he needs to be able to identify the details that support the main idea. He must think about what he reads in order to interpret meaning as well as to get the factual information given.

Reading comprehension also a very complex process that presents many challenges to learners learning to read. In each reading situation the reader needs to possess two kinds of knowledge, the knowledge of the language calls the formal knowledge and the knowledge of 
the substances or the content information. The purpose of reading strategies are to have general knowledge, to get a specific detail, to find the main idea or theme, to learn, to remember, to delight, to summarize and to do research.

The weaknesses of students in reading skills are unquestionable. They lack prior knowledge, which is a very important foundation in getting the gist of the paragraph. Kustaryo $(1988 ; 15)$, reading comprehension problem with the paragraph involves some closely related phenomena; the lacks prior knowledge such as:

(1) Word Recognition

Word Recognition is an important component in understanding target language or native language. Students face difficulties when trying to recognize words of the target language. These difficulties arise because these two languages, English and Indonesia, are not nor branches of the same language and English words are complex

(2) New word recognition

New word and words that have been learned are two aspects that might cause difficulties in the learning vocabulary. Learning new words, words that are introduced for the first time to the students is greatly influenced by their prior knowledge about words.

(3) Other factor

Other factors that might weaken the students when learning a language are the student himself, the teacher, and the educational context.

In teaching reading comprehension, the teacher needs some strategies to make the students comprehend the reading texts. According Brown (2000:306-311), the following are ten strategies which can be applied in the teaching reading comprehension in the classroom:

1. Identifying the purpose in reading

By knowing the purpose of what the reader reads, the reader can throw the unwanted distraction or information. By doing this, students know what information they want to know in reading the texts. (Brown, 2000:306).

2. Using graphemic rules and patterns to aid in bottom up decoding (especially for the beginning level learners)

At the beginning levels of learning English, one of the difficulties that students encounter in learning to read is making the correspondences between spoken and written English. Here teacher also need to teach how to read the sound words with sort vowel sound such as (bat, leg, wish, etc) and the sound words with final silent "e" such as (late, time, bite, etc). (Brown, 2000:306).

3. Using efficient silent reading techniques for relatively rapid comprehension (for intermediate to advanced levels)

In advanced learner, teacher can apply reading fast to reduce time consuming in reading. Readers do not need to pronounce every word and do not need to know the meaning of every word but the comprehension of the text is more important. (Brown, 2000:306).

4. Skimming the text for the main ideas

Skimming is the one of the most valuable reading strategies for learners. Skimming consist of quickly running one's eyes across a whole text (such as an essay, article, or chapter) to find out what the text tells about or to find out the main idea of the text. Skimming gives readers the advantages of being able to guess the purpose of the passage, the main topic, or massage, and possibly some of the developing or supporting ideas (Brown, 2000: 308).

5. Scanning the text for specific information

Scanning is quickly searching for some particular piece or pieces of information that the reader needs in reading a text. Scanning exercises may ask students to look for names or dates, to find a definition of a key concept, or to list a certain number of supporting details (Brown, 2000:308). 
6. Using semantic mapping or clustering

Readers can resume the long string of ideas or events by grouping the important key of the word they get from the reading. The strategy of semantic mapping, or grouping ideas into meaningful clusters, helps the reader to remember the contents of the text. (Brown, 2000:308).

\subsection{Multisensory Teaching Method}

Multisensory means more than one; many sense; one of the five powers of sight, hearing, smell, teach and touch by wich a person is conscious of things(Oxford Advanced Dictionary,1986:852). We learn from information taken in through our basic natural sense: sight, hearing, taste, smell, and touch. According to Ginder (2010), people naturally learn trough multisense, for most of us, we learn best throgh sight and touch, and least through our sense of hearing, alone.

Based on that information, the majority of us would learn best by seeing and doing; the teacher draws the letter "a" on the board, and the students practices duplicating it on their own paper. We show a toddler not only how the round shape fits into the round hole; we give them the toy and allow them to try it themselves. We provide books with soft furry bunnies that the child can touch and flowers that they can smell and they remember those lessons.

Multisensory Teaching Method is very effective for everyone, regardless of age, but for children with learning disabilities, they are critical. Since these disorders cause varying degrees of deficits, in the way the brain processes information gahtered by the senses, furthermore, it is important to know that the students will grasp the informstion with their sense easy and effective if they are grasping based on their learning style; it is their learning style whether they are seeing, hearing, and anything and moving when they are grasping those information during laerning in teaching and learning process. Teachers who rely on single or limited sensory teaching methods will not reach many of these students.

Amstrong (2008:69) said that leraning style is the solution to numerous specific needs. In order to be a more effective educator for all students, teacher need to know a variety of different techniques. Multisensory approach utilizes more than one sense in the teaching process to enhance the learning process of the students. When learning takes place through more than one sense the studentse learning capacities and the retention of the learnt materials have been improved. Most of the teaching in schools is done using either visual or auditory mode (visual or hearing). Multisensory approach is otherwise known as VAKT Method. The four modalities of learning styles have been summarized by the acronym VAKT, for: Visual, Auditory, Kinesthetic and Tactile. The best teaching method is to involve the use of more of the studente"s all the senses, especially the use of touch and movement (kinesthetic). This will give the student"s brain tactile and kinesthetic memories to hang on to, as well as the visual and auditory ones.

Ingham (2009:44) stated that if the children who are not given a learning experience based on the suitable of their leraning needs are bored, we make them in polish. They sholud develop some level of awareness of each child's individul strengths and have enough flexibility to altar lessons to meet them. Not every child has the ability to learn in the same way, regardless of our efforts. If we continue to provide lessons in those same limited styles, we cannot expect the results to change; the child will fail. There are literally countless examples of proven metohod for teaching any subject more effectively with multiple sensory techniques. They can relatively simple, or more complex; they can use conventional means or more innovative methods. There is no wrong way to teach if it helps the students learn; do not discount the effectiveness of even the simp; est modification in teaching.

A method is the practical realization of on approach. The organization of a method arrived of the dicision about types of activities, roles of tacher and learners, the kind of material which 
will be helpful, and some model of syllabus organization. Method includes various procedures and techniques as part of their standard. Richard (2004), using a multisensory taching method means helping a child through more than one of the senses. Since multisensory methods are also known as VAK (Visual, Auditory, Kinesthetic-tactile). It modalities :

According to Bryant (2010). The idea that learning experienced trhough all sense is helpfull in reinforcing memory has a very long history in pedagogy. Multisensory teaching techniques and strategies stimulate leraning by engaging students on multiple levels. They encourage students to use some or all of their sense to :

1) Gather information about a task;

2) Link information to ideas they already know and understand;

3) Perceive the logic involved in solving problems;

4) Learn problem-solving steps;

5) Tap into non verbal reasoning skills;

6) Learn information and store it for later recall.

\section{Method of Research}

The location of this research was conducted at SMP PGRI 3 MEDAN. The research was conducted during 2017/2018 academic year. The reason of chosen this school because there are many students that found difficulties to read English. This research was conducted on February 2018.

The population of this research was taken from seven grade class of SMP PGRI 3 MEDAN at academic year 2017/2018. The population of this research which consist of two classes. There are VII-1 (38), VII-2 (38) and VII-3 (37). The total populations are 113 students. This research was taken the students in VII-1 (38) as the sample by using cluster random sampling. So, the total number of population is 113 and the total sample is 38 .

\section{Discussion}

Table 1. The Calculation Table of Experimental Group

\begin{tabular}{|c|c|c|c|c|c|c|}
\hline No & $\begin{array}{c}\text { Students' } \\
\text { Initial }\end{array}$ & $\begin{array}{c}\text { Pre-Test } \\
(\mathbf{X})\end{array}$ & $\begin{array}{c}\text { Post-Test } \\
(\mathbf{Y})\end{array}$ & $\mathbf{X}^{\mathbf{2}}$ & $\mathbf{Y}^{\mathbf{2}}$ & $\mathbf{X Y}$ \\
\hline 1 & AW & 70 & 85 & 4900 & 7225 & 5950 \\
\hline 2 & AR & 80 & 95 & 6400 & 9025 & 7600 \\
\hline 3 & A A & 60 & 80 & 3600 & 6400 & 4800 \\
\hline 4 & AC & 65 & 80 & 4225 & 6400 & 5200 \\
\hline 5 & AI & 55 & 75 & 3025 & 5625 & 4125 \\
\hline 6 & AH & 50 & 75 & 2500 & 5625 & 3750 \\
\hline 7 & CA & 60 & 80 & 3600 & 6400 & 4800 \\
\hline 8 & DA & 65 & 85 & 4225 & 7225 & 5525 \\
\hline 9 & FS & 70 & 90 & 4900 & 8100 & 6300 \\
\hline 10 & GP & 80 & 95 & 6400 & 9025 & 7600 \\
\hline 11 & HM & 60 & 80 & 3600 & 6400 & 4800 \\
\hline 12 & HL & 75 & 85 & 5625 & 7225 & 6375 \\
\hline 13 & IP & 60 & 80 & 3600 & 6400 & 4800 \\
\hline 14 & LS & 65 & 85 & 4225 & 7225 & 5525 \\
\hline 15 & LD & 70 & 90 & 4900 & 8100 & 6300 \\
\hline 16 & MH & 50 & 75 & 2500 & 5625 & 3750 \\
\hline 17 & MR & 55 & 80 & 3025 & 6400 & 4400 \\
\hline 18 & MZ & 60 & 85 & 3600 & 7225 & 5100 \\
\hline
\end{tabular}




\begin{tabular}{|l|l|l|l|l|l|l|}
\hline 19 & MU & 70 & 90 & 4900 & 8100 & 6300 \\
\hline 20 & MK & 60 & 80 & 3600 & 6400 & 4800 \\
\hline 21 & NN & 65 & 85 & 4225 & 7225 & 5525 \\
\hline 22 & NS & 50 & 75 & 2500 & 5625 & 3750 \\
\hline 23 & NR & 60 & 80 & 3600 & 6400 & 4800 \\
\hline 24 & NY & 70 & 85 & 4900 & 7225 & 5950 \\
\hline 25 & PN & 50 & 75 & 2500 & 5625 & 3750 \\
\hline 26 & RS & 40 & 75 & 1600 & 5625 & 3000 \\
\hline 27 & SA & 45 & 75 & 2025 & 5625 & 3375 \\
\hline 28 & SD & 60 & 80 & 3600 & 6400 & 4800 \\
\hline 29 & SF & 65 & 85 & 4225 & 7225 & 5525 \\
\hline 30 & SM & 45 & 75 & 2025 & 5625 & 3375 \\
\hline 31 & SY & 50 & 75 & 2500 & 5625 & 3750 \\
\hline 32 & SZ & 65 & 85 & 4225 & 7225 & 5525 \\
\hline 33 & SP & 60 & 80 & 3600 & 6400 & 4800 \\
\hline 34 & WR & 55 & 75 & 3025 & 5625 & 4125 \\
\hline 35 & YP & 65 & 80 & 4225 & 6400 & 5200 \\
\hline 36 & Y N & 50 & 75 & 2500 & 5625 & 3750 \\
\hline 37 & Z R & 70 & 90 & 4900 & 8100 & 6300 \\
\hline 38 & HR & 50 & 75 & 2500 & 5625 & 3750 \\
\hline & Total Score & 2295 & 3095 & 142025 & 253375 & 188850 \\
\hline
\end{tabular}

By consulting analyzing of the data, it is clearly stated that there was an effect of multisensory teaching method on the students' reading achievement. It can be simple see from the differences of mean score of Pre-test and Post-test in experimental class. They were 60.39 in pre-test and 81.44 in post-test of experimental class, the mean of pre-test increases after multisensory teaching method from 60.39 to 81.44 .

Based on the testing of hypothesis, the value of $t$-observe $>t$-table. It means that there was a significant effect of multisensory teaching method on the students' reading achievement. The value of the effect was about $82 \%$.

\section{Conclusions}

Based on the data analyzing in Chapter IV, the conclusion can be drawn as the following:

From the determination it was known that effect of multisensory teaching method on the students' reading achievement in reading was $82 \%$ and $18 \%$ was influenced from other factor. Based on the result of the pre-test and post-test the researcher found there was students' achievement in reading comprehension, which is proven from te result of the test $t_{\text {observe }}$ $>t_{\text {table }}$ or $13.3>1.68$. The fact hypothesis $\mathrm{H}_{\mathrm{a}}$ was accepted and $\mathrm{H}_{\mathrm{o}}$ was rejected.

\section{References}

Amstrong, Thomas. 2008. Mulitiple Inteligence in The Classroom. Association for Supervision abd Curriculum Development.

Aswita. 2011. The Effect of Applying Multisensory Teaching Method on The Students",

Vocabulary achievement. A Thesis. UNIMED: English Education Study Program, Faculty of Languages and Arts, Medan State University. Unpublished

Badan Standar Nasional Pendidikan (BSNP). 2006. Standar Kompetensi dan Kompetensi Dasar $S M A / M A$. Jakarta: Depdikbud. 
Bailey, K. M. 2003. Speaking. In Nunan, david (editor), Practical English Languange Teaching. Singapore : McGraw, 2003

Brewster, J. and Ellis, G. 2003. The Primary English Teacher's Guide. New York: Pearson Education Limited.

Brown, H.D. 2004. Language Assessment: Principles and Classroom Practices. New York: Pearson Education.

Burns, Anne. 1984. Doing Action Research in English Language Teaching: A Guide for Practitioners. New York: Routledge.

Cadlin and Hall. 2002. Teaching and Researching Reading. White Plain : Person Education

Edge, Julian. 1984. "Structuring the information gap". ELT Journal Volume 38/4 October 1984, page 1-4.

Harmer, Jeremy. 2007. The Practice of English Language Teaching. 4th Ed. Harlow: Longman.

Haris, Albert. J. 2002. How to Increase Reading Ability. New York: Longman, Inc

Heilman, W. Arthur and etl. 1981. Principle and Practice of Teaching Reading.

Ohio : Bell and Howell.

Ingham. 2009. Multisensory Teaching Method. New York : Longman,Inc.

Jubran,Screen. 2011. Using Multisensory Approach for Teaching English Skills and Its Effect on Students Achievement at Jordian Schools. European Scientific Journal October edition vol. 8, No.22 ISSN: 18577881 (Print) e - ISSN 1857- 7431

Kamala,R. 2014. Multisensory Approach to Reading Skills of Dyslexic Students. IOSR Journal Of Humanities And Social Science (IOSR-JHSS) Volume 19, Issue 5, Ver. II (May. 2014), PP 32.34 e-ISSN: 2279-0837, p-ISSN: 2279-0845. www.iosrjournals.org

Kustaryo, Sukirah. 1998. Reading Techniue for College Students. DEPDIKBUD

Manhaz and Elahe. 2014. The Effect of a Multisensory method combined with Relaxation Techniques on writing Skills and Homework Anxiety in Students with Dysgraphia. International Journal of Psychology and Behavioral Sciences 2014, 4(4): 121-127

Nunan, David. 2003. Practical English Language Teaching. Singapore: McGraw-Hill. Prashing.2009. The context of Language Teaching. Cambridge : Cambridge University Press

Richards, J.C. 2008. Teaching Listening and Speaking From Theory to Practice. Cambridge: Cambridge University Press.

Spratt, Mary, and etl. 2005. The TKT Course. Cambridge: Cambridge University Press.

Sugiyono. 2016. Metode Penelitian Kuantitatif, Kualitatif, dan R \& D. Bandung. Alfabeta Thornbury, S. 2005. How to Teach Speaking. England: Longman. 